\title{
SnO and SnO.CoO nanocomposite as high capacity anode materials for lithium ion batteries
}

B. Das*, M.V. Reddy, B.V.R Chowdari*

Department of Physics, National University of Singapore, Singapore- 117542

* Corresponding author: bijoy822000@gmail.com; phychowd@nus.edu.sg

Tel.: (+65) 6516 2531; Fax.: (+65) 67776126

\begin{abstract}
We prepared $\mathrm{SnO}$ nanoparticles $(\mathrm{SnO}-\mathrm{S})$ and $\mathrm{SnO} . \mathrm{CoO}$ nanocomposites $(\mathrm{SnO} . \mathrm{CoO}-$ B) as anodes for lithium ion batteries (LIBs) by chemical and ball-milling approaches, respectively. They are characterized by X-ray diffraction and TEM techniques. The Listorage performance are evaluated by galvanostatic cycling and cyclic voltammetry. The SnO-S and SnO.CoO-B showed improved cycling performance due to their finite particle size (i.e. nano-size) and presence of secondary phase $(\mathrm{CoO})$. Better cycling stability is noticed for SnO.CoO-B with the expense of their reversible capacity. Also, addition of carbon nanotubes (CNT) to SnO-S further improved the cycling performance of SnO-S. When cycled at $60 \mathrm{~mA} \mathrm{~g}^{-1}$, the first- cycle reversible capacities of 635,590 and $460( \pm 10)$ $\mathrm{mA} \mathrm{h} \mathrm{g}{ }^{-1}$ are noticed for SnO-S, SnO@CNT and SnO.CoO-B, respectively. The capacity fading observed are 3.7 and $1.8 \mathrm{~mA} \mathrm{~h} \mathrm{~g}^{-1}$ per cycle for SnO-S and SnO@CNT, respectively; whereas 1-1.2 $\mathrm{mA} \mathrm{h} \mathrm{g}^{-1}$ per cycle for SnO.CoO-B. All the samples show high coulombic efficiency, $96-98 \%$ in the range of 5-50 cycles.
\end{abstract}

Key words: Oxides; Chemical synthesis; Transmission electron microscopy; Electrochemical properties; Energy storage. 


\section{Introduction}

Nanomaterials are widely studied for different applications due to their improved properties. These materials are tailored to different sizes and structures to improve their performance [1-4]. They are also found to be used extensively as electrode materials for energy storage, for example in lithium ion batteries (LIBs) and super capacitors [5-10]. Due to their finite size ( nanometer) and high surface area, they are beneficial for energy storage devices. They show fast Li- ion diffusion due to their reduced particle sizes to few order of nanometer $\left(\tau=\mathrm{L}^{2} / \mathrm{D}_{\mathrm{Li}}\right)$ [10]. Graphite is mostly being used as negative electrode material for commercial LIBs. It is excellent as negative electrode material due to its excellent cycling performance in terms of long cycle life. However, it suffers from low specific capacity (Theoretical: $372 \mathrm{~mA} \mathrm{~h} \mathrm{~g}^{-1}$ ) and hence low specific energy. The reversible reaction involves intercalation/de- intercalation of maximum up to $1 \mathrm{Li}^{+}$per $\mathrm{C}_{6}$ and as a result ended up with low specific capacity. However, carbon in the form of CNTs and graphene are also employed as negative electrode for LIBs and they delivered higher specific capacity compared to graphite and explained as storage of more than $1 \mathrm{Li}^{+}$[11-13]. The high surface area is the barrier for their practical use as negative electrode materials, as the volumetric energy density is very poor, as well as they can decompose electrolyte when discharge to low voltage. Transition metal oxides are opted as the alternative to graphite as possible electrode materials. They can deliver high reversible specific capacity based on 'conversion reaction' $\left(\mathrm{MO}+2 \mathrm{Li} \leftrightarrow \mathrm{M}+\mathrm{Li}_{2} \mathrm{O} ; \mathrm{M}=\mathrm{Co}, \mathrm{Ni}, \mathrm{Cu}, \mathrm{Fe}\right.$ etc.) [14- 17]. Group of Tarascon first reported the conversion reaction mechanism in case of transition metal oxides, where they undergo structural transformation and formation of metal nanoparticles $(\sim 2-3 \mathrm{~nm})$ embedded in amorphous $\mathrm{Li}_{2} \mathrm{O}$ [14]. In spite of their high specific capacity, they suffer from high operating voltage and large voltage hysteresis. 
Sn- based oxides and its intermetallic are widely used as negative electrode materials due to their high theoretical capacity. The $\mathrm{Sn}$ forms alloy with $\mathrm{Li}$ to form $\mathrm{Li}_{\mathrm{x}} \mathrm{Sn} ; 0 \leq \mathrm{x} \leq 4.4$, as a result shows high theoretical capacity $\left(994 \mathrm{~mA} \mathrm{~h} \mathrm{~g}^{-1}\right)$. The low alloying/de-alloying voltage and low voltage hysteresis are two major advantages of Sn- based electrode materials. However, they suffer from large volume change $(\sim 300 \%)$; as a result severe capacity degradation is noticed. The large volume change causes electrode disintegraty and hence electrical contact is lost from current collector. In order to overcome such problem of large volume change, nano-structuring of electrodes [18, 19], precise carbon coating $[20,21]$ and introducing secondary phases [22- 26] approaches to Sn based electrode materials were adopted. It was noticed that after such treatment, they showed better capacity retention. SnO and $\mathrm{SnO}_{2}$ are well studied as negative electrode materials for LIBs. They show high reversible capacity $\left(\sim 875 \mathrm{~mA} \mathrm{~h} \mathrm{~g}^{-1}\right.$ for $\mathrm{SnO}$ and $782 \mathrm{~mA} \mathrm{~h} \mathrm{~g}^{-1}$ for $\mathrm{SnO}_{2}$ considering $\mathrm{Li}_{4.4} \mathrm{Sn}$ reaction) and are also easy to prepare. However, $\mathrm{SnO}$ and $\mathrm{SnO}_{2}$ suffer from capacity degradation due to large volume change associated during cycling. These issues were addressed with various approaches. Tian et al. prepared a $\mathrm{SnO}_{2} / \mathrm{C}$ composite of ultra-small $\mathrm{SnO}_{2}$ nanoparticles $(\sim 6 \mathrm{~nm})$ by a hydrothermal method. They showed a reversible capacity of $839 \mathrm{~mA} \mathrm{~h} \mathrm{~g}^{-1}$ at $200 \mathrm{~mA} \mathrm{~g}^{-1}$ after 217 cycles and $713 \mathrm{~mA} \mathrm{~h} \mathrm{~g}^{-1}$ at $800 \mathrm{~mA} \mathrm{~g}^{-1}$ after 378 cycles [27]. Hu et al. reported the synthesis of $\mathrm{SnO}$ nanoplates by flame synthesis and showed a high initial reversible capacity of $945 \mathrm{~mA} \mathrm{~h} \mathrm{~g}^{-1}$ at $100 \mathrm{~mA} \mathrm{~g}^{-1}$. They explained as nanosize of $\mathrm{SnO}$ is beneficial for high reversible capacity and also better capacity retention [28]. Zhang et al. reported the synthesis of $\mathrm{SnO}$ ultrathin nanosheets by hydrothermal process and showed a high reversible capacity of $559 \mathrm{~mA} \mathrm{~h} \mathrm{~g}^{-1}$ after 20 cycles. They claimed unique structure of $\mathrm{SnO}$ is responsible for better cycling performance [29]. Tian et al. prepared the $\mathrm{SnO}_{2} / \mathrm{TiO}_{2} / \mathrm{C}$ hollow microsphere by facile hydrothermal strategy. They showed excellent cycling performance of $\mathrm{SnO}_{2} / \mathrm{TiO}_{2} / \mathrm{C}$ due to the hollow structure and presence of $\mathrm{TiO}_{2}$ as secondary 
phase. The composite showed stable capacity of $\sim 500 \mathrm{~mA} \mathrm{~h} \mathrm{~g}^{-1}$ for 500 cycles at $200 \mathrm{~mA} \mathrm{~g}^{-1}$ [30]. Liu et al. prepared amorphous nanomembrane of $\mathrm{SnO}_{2}$ and showed a high capacity of $854 \mathrm{~mA} \mathrm{~h} \mathrm{~g}^{-1}$ stable for 1000 cycle at $1600 \mathrm{~mA} \mathrm{~g}^{-1}$. They explained the superior performance of $\mathrm{SnO}_{2}$ is due to the structural features of amorphous $\mathrm{SnO}_{2}$ [31]. Earlier, our group reported the preparation and $\mathrm{Li}$ - storage performance of $\mathrm{M}_{1 / 2} \mathrm{Sb}_{1 / 2} \mathrm{SnO}_{4}(\mathrm{M}=\mathrm{V}, \mathrm{Fe}, \mathrm{In})$ [22-25], $\mathrm{SnO}\left(\mathrm{VO}_{\mathrm{x}}\right)$ nanocomposite [26] and Sn- hollandites $\mathrm{K}_{2} \mathrm{M}_{2} \mathrm{Sn}_{6} \mathrm{O}_{16}(\mathrm{M}=\mathrm{Co}$, In) [32] and showed improved cycling performance due to the presence of secondary phases.

In the present study, we report the Li storage of chemically prepared $\mathrm{SnO}(\mathrm{SnO}-\mathrm{S})$ nanoparticles and ball milled $\mathrm{SnO} . \mathrm{CoO}(\mathrm{SnO} . \mathrm{CoO}-\mathrm{B})$ nanocomposite, respectively and compared to that of the commercial micron- size $\mathrm{SnO}(\mathrm{SnO}-\mathrm{C})$ and ball milled $\mathrm{SnO}(\mathrm{SnO}-\mathrm{B})$. The $\mathrm{SnO}$ nanoparticles are prepared at relatively low temperature in order to limit the growth of particles and also to stop the transformation of $\mathrm{SnO}$ to $\mathrm{SnO}_{2}$. The $\mathrm{SnO}-\mathrm{S}$ and $\mathrm{SnO}$.CoO-B showed improved cycling performance when they are prepared to nano-size and also the presence of secondary phase $(\mathrm{CoO})$. We also notice further improvement in cycling of SnO-S when carbon nanotube $(\mathrm{CNT})$ is introduced during electrode preparation. The reduction in particle size and presence of secondary phase improved the cycling performance of $\mathrm{SnO}$ compared to that of SnO-C and SnO-B. The SnO.CoO-B showed almost a stable capacity until $50^{\text {th }}$ cycle, whereas low specific capacity is observed as $\mathrm{CoO}$ is electrochemically inactive in this potential window. SnO-S and $\mathrm{SnO} @ \mathrm{CNT}$ showed high reversible capacity with low capacity fading until $50^{\text {th }}$ cycle. The coulombic efficiency for all is $96-98 \%$ after $5^{\text {th }}$ cycle.

\section{Experimental}

\subsection{Synthesis of SnO nanoparticles and SnO.CoO nanocomposite}

For the synthesis of $\mathrm{SnO}$ nanoparticles, the chemicals were used as received without further purification. The $\mathrm{SnCl}_{2} .2 \mathrm{H}_{2} \mathrm{O}(0.02 \mathrm{M} ; 4.51 \mathrm{~g})$ was mixed with $\mathrm{NaOH}(0.04 \mathrm{M} ; 1.6 \mathrm{~g})$ 
and ground in a mortar. During grinding, $\mathrm{NaCl}$ was added to the mixture to prevent the growth of particles as well as agglomeration. The mixture was collected and heated inside a tube furnace (Carbolite, UK) to an elevated temperature of $200{ }^{\circ} \mathrm{C}$ in flowing Ar- gas for 3 hours. After heating, the powder was collected and ground to fine powder followed by washing in distilled $\mathrm{H}_{2} \mathrm{O}$ and drying at room temperature. The experimental procedure for the synthesis was followed from literature with some modifications [33]. The $\mathrm{SnO}$ nanoparticles prepared by chemical route are written as $\mathrm{SnO}-\mathrm{S}$ hereafter.

$$
\begin{array}{r}
\mathrm{SnCl}_{2} \cdot 2 \mathrm{H}_{2} \mathrm{O}+2 \mathrm{NaOH} \rightarrow \mathrm{Sn}(\mathrm{OH})_{2}+2 \mathrm{NaCl} \\
\downarrow 200^{\circ} \mathrm{C}, 3 \mathrm{~h}, \mathrm{Ar} \\
\mathrm{SnO}
\end{array}
$$

For the synthesis of $\mathrm{CoO} . \mathrm{SnO}$ nanocomposites, different compositions of $\mathrm{SnO}$ to $\mathrm{CoO}$ were prepared by high energy ball milling (HEB) under inert condition. Mechanical ballmilling is one of the effective methods to prepare various nanomaterials and their composites for improved energy storage performance [34-36]. The commercial SnO (Acros Organics, $98 \%)$ and $\mathrm{CoO}$ were used as starting materials for ball milling. Appropriate amount ( 2.5 g) was weighed keeping different molar ratios of $\mathrm{SnO}$ to $\mathrm{CoO}$ and transferred to stainless steel vial inside in an Ar-filled glove box (MBraun, Germany). The vial was set for HEB at a speed of 1,400 rpm using Spex, 8000D, USA instrument. The ball milling was carried out using stainless steel balls maintaining ball-to active mass ratio of $4: 1$ for $18 \mathrm{~h}$, in three steps of $6 \mathrm{~h}$ each, to avoid significant rise in temperature inside the vial. The detailed experimental procedure is similar to our previous reports $[26,32]$. For the sake of convenience, the nanocomposites prepared by $\mathrm{HEB}$ are, $3 / 4 \mathrm{SnO}, 1 / 4 \mathrm{CoO}$ and $2 / 3 \mathrm{SnO} .1 / 3 \mathrm{CoO}$. The $\mathrm{CoO}$ used for the synthesis was prepared by carbothermal reduction at $750{ }^{\circ} \mathrm{C}$ in $\mathrm{Ar}-$ gas atmosphere. The SnO.CoO nanocomposite prepared by ball milling is written as $\mathrm{SnO} . \mathrm{CoO}-\mathrm{B}$ hereafter.

The structure and morphology of SnO-S and SnO.CoO-B were analyzed by X-ray diffraction (XRD) using Philips X'PERT MPD unit $\left(\mathrm{Cu} \mathrm{K}_{\alpha}\right.$ radiation) and high resolution 
transmission electron microscopy (HR-TEM) and selected area electron diffraction (SAED) (JEOL JEM 3010 operating at $300 \mathrm{kV}$ ). For electrochemical measurement, electrodes were prepared from active materials (Here, SnO-S, SnO.CoO-B etc.), carbon black (Super P, MMM) and binder (PVDF) in the weight ratio of 70-15-15. In case of $\mathrm{SnO} @ \mathrm{CNT}$ electrode preparation, the CNT was used in place of Super P carbon black. They are mixed well by grinding. Homogeneous slurry was prepared using N-methyl-pyrrolidinone (NMP) as solvent. Thick film of $15 \mu \mathrm{m}$ was prepared by coating the slurry onto the etched $\mathrm{Cu}$ - foil (10 $\mu \mathrm{m}$, Alpha Industries Co. Ltd., Japan) using doctor bled technique followed by drying inside the vacuum to evaporate the NMP. The electrodes were cut to disc of $\varnothing=16 \mathrm{~mm}$ before assembling the cells. Coin cells (2016) were fabricated inside the Ar- filled glove box (MBraun, Germany). The level of $\mathrm{H}_{2} \mathrm{O}$ and $\mathrm{O}_{2}$ was maintained $<1$ ppm inside the glove box. The Li- metal (Kyokuto Metal Co., Japan) was used as counter electrode. The glass microfiber filter (GF/F) (Whatman Int. Ltd, Maidstone, England) was used as the separator and $1 \mathrm{M} \mathrm{LiPF}_{6}$ dissolved in ethylene carbonate $(\mathrm{EC})+$ diethyl carbonate $(\mathrm{DMC})$ in the ratio of 1:1 volume (Merck) as the electrolyte. The electrode preparation and cell fabrications are discussed in detailed in our previous reports [37-40]. The cells were aged for $12 \mathrm{~h}$ prior to testing in order to ensure complete percolation of electrolytes into the electrodes. The electrochemical performances were evaluated by both galvanostatic and cyclic voltammetry (CV) modes using galvanostatic cycler (model SCN, Bitrode, USA) and Macpile II system; Biologic, France instruments at room temperature, respectively.

\section{Results and Discussion}

\subsection{Structure and morphology}

The structures of SnO-S and SnO.CoO-B nanocomposite were analyzed by using XRD measurement. Fig.1a shows the XRD pattern of SnO-S nanoparticles prepared by solid state reaction at low temperature. The pattern shows the pure phase formation of $\mathrm{SnO}$ and 
belonged to tetragonal crystal structure with I4/mna space group (PDF: 00-001-0902) [28, 29]. The peaks observed at $18.3^{\circ}, 30.0^{\circ}, 33.4^{\circ}$ and $37.2^{\circ}$ can be assigned to the diffraction planes of $\mathrm{SnO}(001), \mathrm{SnO}(101), \mathrm{SnO}(110)$ and $\mathrm{SnO}(002)$, respectively. Fig. 1b shows the XRD patterns of SnO-B and SnO.CoO-B nanocomposite. The XRD pattern of SnO-B is given for comparison. The characteristic peaks observed for $\mathrm{SnO}-\mathrm{B}$ can be assigned to $\mathrm{SnO}_{2}$ (PDF: 00041-1445) and Sn (PDF:00-004-0673). It is noticed that the $\mathrm{SnO}$ is unstable to high energy ball milling and disproposnated to $\mathrm{SnO}_{2}$ and $\mathrm{Sn}$ (Eqn.2). This is due to the thermodynamically instability of $\mathrm{SnO}$, which disproposnate to $\mathrm{SnO}_{2}$ and $\mathrm{Sn}$ as per Eqn.2.

$2 \mathrm{SnO} \rightarrow \mathrm{SnO}_{2}+\mathrm{Sn}$

The detailed mechanism is discussed in the previous report $[26,41]$. The XRD pattern of SnO.CoO-B shows the mixture of $\mathrm{SnO}_{2}$ (PDF: 00-041-1445), SnO (PDF: 00-001-0902) and in-situ formed Co (PDF: 00-004-1507). The assigned ( $h k l$ ) values are due to $\mathrm{SnO}_{2}$ characteristic peaks (Fig.1b). During ball milling, the $\mathrm{SnO}$ decomposed to $\mathrm{SnO}_{2}$, $\mathrm{Sn}$ and further reduction of $\mathrm{CoO}$ was noticed. The freshly formed $\mathrm{Sn}$ possibly reduced $\mathrm{CoO}$ to form $\mathrm{SnO}$ and $\mathrm{Co}$, which is confirmed from the diffraction pattern of SnO.CoO-B nanocomposite (Fig.1b). This reaction mechanism is also thermodynamically favorable, as the Gibbs' free energy of formation is negative $(\Delta \mathrm{G}=-47 \mathrm{~kJ} / \mathrm{mol})$ for the forward reaction (Eqn.3).

$$
\mathrm{Sn}+\mathrm{CoO} \rightarrow \mathrm{SnO}+\mathrm{Co}
$$

The morphology of SnO-S and SnO.CoO-B was analyzed by using TEM. Fig. 2a-d show the TEM micrographs of SnO-S. It can be clearly seen from Fig.2a-c that nanoparticles of $\mathrm{SnO}$ of particle size ranging from $20-30 \mathrm{~nm}$ (even some particles are smaller than $20 \mathrm{~nm}$ ) are well dispersed without much agglomeration. No definite morphology for $\mathrm{SnO}$ nanoparticles is noticed. The dispersion of these $\mathrm{SnO}$ nanoparticles is due to the addition of $\mathrm{NaCl}$ which prevented the agglomeration of $\mathrm{SnO}$ nanoparticles during synthesis. The HRTEM lattice image is shown in Fig. 2 d, where the d- spacing (inter planar distance) of the 
plane is $2.96( \pm 0.02) \AA$ and this corresponds to the Miller indices (101) of SnO (Fig. 1a). The electron diffraction pattern (Inset of Fig.2a) shows the formation of pure phase $\mathrm{SnO}$ and corroborates to XRD pattern (Fig.1a). The diffraction pattern shows highly resolved concentric rings and some bright spots indicating the nanocrystalline nature of $\mathrm{SnO}$. The TEM micrographs of SnO.CoO-B nanocomposite are given in Fig. 2e, f. It is noticed that the nanoparticles of 15-20 $\mathrm{nm}$ are agglomerated to form large particles. They did not show definite morphology. The TEM image of SnO.CoO-B (Fig. 2 e,f) confirms the reduction of particle size to nanometer scale due to high energy ball milling. Such effect is also observed in the XRD pattern (Fig.1b) reflected from the broadening of XRD peaks. The d- values calculated from Fig.2f refer to the $\mathrm{SnO}_{2}$ and Co phases in the SnO.CoO-B nanocomposite. The calculated d- values are 3.38, 2.67, 2.38 and $2.09( \pm 0.04) \AA$, which correspond to (110), (101) and (200) due to $\mathrm{SnO}_{2}$; whereas (111) due to Co- metal, respectively.

\subsection{Electrochemical properties}

\subsubsection{Cyclic voltammetry of SnO-S and SnO.CoO-B}

Fig. 3a shows the cyclic voltammograms (CVs) of SnO-S for 1-6 cycles at $58 \mu \mathrm{V} \mathrm{s}^{-1}$ in the voltage window of $0.005-1.0 \mathrm{~V}$. The upper cut-off voltage was selected based on formation/decomposition of $\mathrm{Li}_{\mathrm{x}} \mathrm{Sn}(0 \leq \mathrm{x} \leq 4.4)$, restricting the reversible formation of $\mathrm{SnO}$ during charge process to minimize the volume change and hence, stabilization of capacity fading [15]. It can be seen from the first discharge (cathodic) sweep, no voltage plateaus are noticed until 1.0 V. Thereafter, two intense and broad voltage peaks are noticed when discharged further to $0.005 \mathrm{~V}$. The voltage peak noticed at $\sim 0.75 \mathrm{~V}$ is due to the structural transformation of $\mathrm{SnO}$ to nano-Sn and amorphous $\mathrm{Li}_{2} \mathrm{O}$ [Eqn.4]. Whereas the voltage peaks noticed at $\sim 0.27$ and $0.17 \mathrm{~V}$ are due to the formation of alloy $\operatorname{Li}_{\mathrm{x}} \operatorname{Sn}(0 \leq \mathrm{x} \leq 4.4)$ [Eqn.6] and solid electrolyte interface (SEI) [14, 15, 41-44].

$\mathrm{SnO}+2 \mathrm{Li}^{+}+2 \mathrm{e}^{-} \rightarrow \mathrm{Sn}+\mathrm{Li}_{2} \mathrm{O}$ 
$\mathrm{SnO}_{2}+4 \mathrm{Li}^{+}+4 \mathrm{e}^{-} \rightarrow \mathrm{Sn}+2 \mathrm{Li}_{2} \mathrm{O}$

$\mathrm{Sn}+\mathrm{x} \mathrm{Li}^{+}+\mathrm{x} \mathrm{e}^{-} \leftrightarrow \operatorname{Li}_{\mathrm{x}} \mathrm{Sn}(0 \leq \mathrm{x} \leq 4.4)$

During the subsequent charging, the $\mathrm{CV}$ shows a high intense peak at $\sim 0.52 \mathrm{~V}$ and a shoulder peak at $\sim 0.65 \mathrm{~V}$, which are due to the de-alloying of $\mathrm{Li}_{\mathrm{x}} \mathrm{Sn}$ (formed in the previous discharge process) [Eqn.6], indicating that the de-alloying occurred in stages [23]. The CVs from 2-6 cycles represent the reversible formation/or de-composition of $\mathrm{Li}_{\mathrm{x}} \mathrm{Sn}$. With increase in the cycle number, the area under the I/V curves decreased, indicating capacity degradation.

Fig. $3 \mathrm{~b}$ shows the $\mathrm{CVs}$ of $\mathrm{SnO} \cdot \mathrm{CoO}-\mathrm{B}$ nanocomposite prepared by ball milling approach in the voltage window of $0.005-0.8 \mathrm{~V}$ at a scan rate of $58 \mu \mathrm{V} \mathrm{s}^{-1}$. It was noticed that during ball milling of $\mathrm{SnO}$ and $\mathrm{CoO}$, the major product $\mathrm{SnO}_{2}$ was formed along with $\mathrm{Co}$ and $\mathrm{SnO}$ (less than $5 \mathrm{wt} . \%$ and hence neglected compared to $\mathrm{SnO}_{2}$ ) as secondary phases (Fig1b). The CVs noticed in Fig. $3 \mathrm{~b}$ are due to typical $\mathrm{SnO}_{2}$. During first discharge, the CV profile shows a high intense peak at $\sim 0.9 \mathrm{~V}$ due to the structural transformation of $\mathrm{SnO}_{2}$ to $\mathrm{Sn}$ and $\mathrm{Li}_{2} \mathrm{O}$ [Eqn.5] and followed by a broad voltage peak at $\sim 0.17 \mathrm{~V}$. The later voltage plateau corresponds to the $\mathrm{Li}_{\mathrm{x}} \mathrm{Sn}$ and SEI formation $[14,15,41-44]$. In the subsequent charging, the $\mathrm{CV}$ shows a high intense peak at $\sim 0.5 \mathrm{~V}$, indicating the de-alloying of $\mathrm{Li}_{\mathrm{x}} \mathrm{Sn}$ [Eqn. 6].The CVs from 2-6 cycles overlap each other indicating excellent reversibility. The area under the $\mathrm{I} / \mathrm{V}$ curves remained same with increase in cycle number indicating stable cycling performance.

\subsubsection{Galvanostatic cycling of SnO-S, SnO@CNT and SnO.CoO-B nanocomposite}

The Li- storage performance of $\mathrm{SnO}-\mathrm{S}$ and $\mathrm{SnO} @ \mathrm{CNT}$ was evaluated by galvanostatic cycling in the voltage window of $0.005-0.8 \mathrm{~V}$ vs. Li at a current density of 60 $\mathrm{mA} \mathrm{g}^{-1}$ and the discharge- charge profiles for selected cycles are shown in Fig.4. The voltage vs. capacity profiles of SnO-S are shown in Fig.4a, b for $1^{\text {st }}, 2^{\text {nd }}, 10^{\text {th }}$ and $50^{\text {th }}$ cycles, respectively. In the first discharge, it shows a voltage plateau at $\sim 1.0 \mathrm{~V}$, which corresponds 
to a discharge capacity of $\sim 404 \mathrm{~mA} \mathrm{~h} \mathrm{~g}^{-1}$ (consumption of $\sim 2.03$ mole of Li per formula unit of $\mathrm{SnO}$ ). This corresponds to the structural transformation of $\mathrm{SnO}$ to $\mathrm{Sn}$ and $\mathrm{Li}_{2} \mathrm{O}$ (Eqn.4). Thereafter, a sloping profile is noticed until $0.005 \mathrm{~V}$. The first discharge capacity noticed at the end of $0.005 \mathrm{~V}$ is $1725( \pm 10) \mathrm{mA} \mathrm{h} \mathrm{g}^{-1}(\sim 8.66$ moles of Li). The total first discharge capacity is due to the structural transformation of $\mathrm{SnO}$ and followed by formation of $\mathrm{Li}_{\mathrm{x}} \mathrm{Sn}$ alloy and SEI layer. From Eqns. $4 \& 6$, it is expected that theoretically 6.4 moles of Li can be consumed during first discharge. However, $~ 8.66$ moles of Li were consumed at the end of first discharge with excess of $\sim 2.26$ moles. The extra capacity is due to the formation of SEI layer $[14,15,41-44]$. In the subsequent charging to $0.8 \mathrm{~V}$, it shows a total capacity of 635 $( \pm 10) \mathrm{mA} \mathrm{h} \mathrm{g}^{-1}(\sim 3.2$ moles of Li) with first cycle coloumbic efficiency as low as $\sim 37 \%$ (Fig.6c). The reversible charge capacity is due to the de-alloying of $\mathrm{Li}_{\mathrm{x}} \mathrm{Sn}$ (Eqn.6). Fig.4b shows the discharge- charge profiles from 2- 50 cycles. It can be seen that these dischargecharge profiles are due to the alloying/de-alloying reaction of Sn with Li. The reversible capacity observed at the end of $50^{\text {th }}$ cycles is $450( \pm 10) \mathrm{mA} \mathrm{h} \mathrm{g}^{-1}(\sim 2.26$ moles of Li $)$. With increase in cycle number, the capacity fading is observed with $3.7 \mathrm{~mA} \mathrm{~h} \mathrm{~g}^{-1}$ per cycle. The coulombic efficiency at the end of $50^{\text {th }}$ cycle is noticed, as $98 \%$. The galvanostatic dischargecharge profiles of $\mathrm{SnO} @ \mathrm{CNT}$ at $60 \mathrm{~mA} \mathrm{~g}^{-1}$ in the voltage window of $0.005-0.8 \mathrm{~V}$ vs. Li are shown in Fig.4c,d for $1^{\text {st }}, 2^{\text {nd }}, 10^{\text {th }}$ and $50^{\text {th }}$ cycles, respectively. It is noticed that similar discharge- charge profiles are observed for SnO@CNT. However, the observed capacities values are slightly different compared to that of $\mathrm{SnO}-\mathrm{S}$. It shows first discharge capacity of $1810( \pm 10) \mathrm{mA} \mathrm{h} \mathrm{g}^{-1}\left(\sim 9.09\right.$ moles of Li), whereas first charge capacity is $590( \pm 10) \mathrm{mA} \mathrm{h} \mathrm{g}^{-1}$ ( 2.96 moles of Li) with first cycle coulombic efficiency of $33 \%$. Such low coulombic efficiency for SnO@CNT compared to that of SnO-S is possibly due to the presence of CNT of high surface area, which consumes excess Li during discharge reaction. At the end of $50^{\text {th }}$ cycles, it shows a reversible capacity of $500( \pm 10) \mathrm{mA} \mathrm{h} \mathrm{g}^{-1}(\sim 2.51$ moles of Li) with capacity 
fading of $1.8 \mathrm{~mA} \mathrm{~h} \mathrm{~g}^{-1}$ per cycle. The capacity retention is better compared to $\mathrm{SnO}-\mathrm{S}$ due to the presence of CNT, which provide additional electronic conductivity as well as buffer the volume change.

The galvanostatic discharge- charge cycling profiles of SnO.CoO-B nanocomposite in the voltage range of $0.005-0.8 \mathrm{~V}$ vs. $\mathrm{Li}$ and at a current density of $60 \mathrm{~mA} \mathrm{~g}^{-1}$ are shown in Fig. 5a, b. The capacity is calculated w.r.t. the total weight of the composite. The observed capacity is due to reversible reaction of $\mathrm{Sn}$ with $\mathrm{Li}$ in this voltage window. However, the voltage vs. capacity profiles of $3 / 4 \mathrm{SnO}$. $1 / 4 \mathrm{CoO}$ composition is given as they are similar to that of $2 / 3 \mathrm{SnO} \cdot 1 / 3 \mathrm{CoO}$ composition. It was noticed that during ball milling, the major phases formed are $\mathrm{SnO}_{2}$ with Co- metal and $\mathrm{SnO}$ as secondary phases (Fig.1b). However, Co- metal does not contribute to the observed capacity (since Co is inactive matrix element), whereas the discharge- charge profiles are due to the $\mathrm{SnO}_{2}$. During the first discharge process, a sloping profile is noticed with a prominent voltage plateau at $\sim 0.9 \mathrm{~V}$. This voltage plateau is due to the structural transformation of $\mathrm{SnO}_{2}$ to $\mathrm{Sn}$ and $\mathrm{Li}_{2} \mathrm{O}$ (Eqn.5). This is followed by a sloping profile until the discharge voltage, $0.005 \mathrm{~V}$ with no major voltage plateaus noticed. The first discharge capacity observed at the end of $0.005 \mathrm{~V}$ is $1395( \pm 10) \mathrm{mA} \mathrm{h} \mathrm{g}^{-1}$. The first charge capacity when cycled to $0.8 \mathrm{~V}$ is $460( \pm 10) \mathrm{mA} \mathrm{h} \mathrm{g}^{-1}$, which is due to the de-alloying of $\mathrm{Li}_{\mathrm{x}} \mathrm{Sn}$ formed during the previous discharge, and is reflected by the voltage plateau noticed at $\sim 0.5 \mathrm{~V}$. The SnO.CoO-B shows first cycle coulombic efficiency of $33 \%$. Such low coulombic efficiency is due to the irreversible Li stored in the defects formed due to high energy ball milling. The discharge-charge profiles from $2-50^{\text {th }}$ cycles (Fig. $5 \mathrm{~b}$ ) are due to the alloying/de-alloying reaction of $\mathrm{Sn}$. At the end of $50^{\text {th }}$ cycle, the reversible charge capacity noticed is $400( \pm 10) \mathrm{mA} \mathrm{h} \mathrm{g}^{-1}$ with $50^{\text {th }}$ cycle coulombic efficiency as high as $98 \%$. The capacity fading noticed for $\mathrm{SnO} . \mathrm{CoO}-\mathrm{B}$ nanocomposite is almost negligible, which is $1.2 \mathrm{~mA}$ $\mathrm{h} \mathrm{g}^{-1}$ per cycle. The differential capacity vs. voltage profiles of SnO.CoO-B extracted from 
their discharge/charge profile are shown in Fig.5c,d for $1^{\text {st }}, 2^{\text {nd }}$ and $50^{\text {th }}$ cycles, respectively. They show the voltage plateaus which are not clearly noticed in discharge-charge profiles. These voltage plateaus resembles with the plateaus noticed during CV measurement (Fig.3b). The capacity vs. cycle number plots for SnO-C, SnO-S, SnO-B and SnO@CNT up to 50 cycles $\left(22\right.$ cycles for SnO-C) at $60 \mathrm{~mA} \mathrm{~g}^{-1}$ current density are shown in Fig.6a. In the present study, we compared the Li- cycling performance of SnO-S and $\mathrm{SnO} @ \mathrm{CNT}$ with that of $\mathrm{SnO}-\mathrm{C}$ and $\mathrm{SnO}-\mathrm{B}$. The detailed Li-storage performance of $\mathrm{SnO}-\mathrm{B}$ is discussed in our previous report [26]. It can be seen that all the samples; SnO-C, SnO-B, SnO-S and SnO@CNT show high initial discharge capacities, 1500, 1510,1725, $1810( \pm 10) \mathrm{mA} \mathrm{h} \mathrm{g}{ }^{-1}$, respectively. When charged to $0.8 \mathrm{~V}$, they show high first cycle reversible capacities of 660 , 575,635 and $590( \pm 10) \mathrm{mA} \mathrm{h} \mathrm{g}^{-1}$, with first cycle coulombic efficiencies as 44, 38, 37 and 33 $\%$, respectively. The SnO-S showed capacity fading when cycled until 50 cycles and the reversible charge capacity at the end of $50^{\text {th }}$ cycle is $450( \pm 10) \mathrm{mA} \mathrm{h} \mathrm{g}^{-1}$. The capacity fading for $\mathrm{SnO}-\mathrm{S}$ is $3.7 \mathrm{~mA} \mathrm{~h} \mathrm{~g}^{-1}$ per cycle (Table.1). The SnO@CNT showed almost a stable capacity until $50^{\text {th }}$ cycle and the reversible capacity noticed is $500( \pm 10) \mathrm{mA} \mathrm{h} \mathrm{g}^{-1}$. The capacity fading for $\mathrm{SnO} @ \mathrm{CNT}$ is $1.8 \mathrm{~mA} \mathrm{~h} \mathrm{~g}^{-1}$ per cycle. It can be seen that both $\mathrm{SnO}-\mathrm{S}$ and SnO@CNT show better capacity retention compared to that of SnO-C and SnO-B.(Table.1 and Ref. 26). The SnO@CNT shows the best Li-cycling performance among all with least capacity fading. The improved $\mathrm{Li}$ - storage performance and better capacity retention is possibly due to the presence of CNT, which provide better electronic conductivity and accommodate the volume change during cycling. At the end of $50^{\text {th }}$ cycle, all the samples showed 96-98 \% coulombic efficiency (Fig.6c). The calculated specific energy of SnO-C, SnO-B, SnO-S and SnO-CNT are 330, 288, 318 and $295( \pm 5) \mathrm{W}$ h/kg, respectively.

Fig. $6 \mathrm{~b}$ shows the capacity vs. cycle number plots for SnO.CoO-B of different compositions up to 50 cycles at $60 \mathrm{~mA} \mathrm{~g}^{-1}$ current density. The capacities for different cycles 
along with capacity fading and coulombic efficiencies are mentioned in Table.1. It can be seen from Fig. $6 \mathrm{~b}$ that both composition showed almost same discharge and charge capacities until $50^{\text {th }}$ cycles. However, the composition with higher $\mathrm{CoO}$ wt.\% showed slightly lower capacity as $\mathrm{CoO}$ did not contribute to the total capacity in this voltage range. The composition with higher $\mathrm{CoO}$ wt.\% showed better capacity retention when cycled until 50 cycles and the capacity fading is $1.0 \mathrm{~mA} \mathrm{~h} \mathrm{~g}^{-1}$ per cycle against the lower $\mathrm{CoO}$ wt.\% composition which showed $1.2 \mathrm{~mA} \mathrm{~h} \mathrm{~g}^{-1}$ per cycle. This observation is expected as presence of $\mathrm{CoO}$ helps to buffer the volume change of SnO during cycling. It can be seen that the better capacity retention was noticed for $\mathrm{SnO}$. CoO-B composite compared to $\mathrm{SnO}-\mathrm{C}, \mathrm{SnO}-\mathrm{S}$ and $\mathrm{SnO}-\mathrm{B}$. This effect can be explained as the presence of secondary phase $(\mathrm{CoO}$ in this study). Hence, the reduction of particle size as well as presence of secondary phase are beneficial for better Li-storage performance and long term cycling. The capacity retention of SnO.CoO-B is little higher compared to SnO@CNT. However, the SnO.CoO-B suffers from low specific capacity. Both the composition show high first discharge capacity of 1395 and $1365( \pm 10) \mathrm{mA} \mathrm{h} \mathrm{g}^{-1}$, whereas the first charge capacities are 460 and $445( \pm 10) \mathrm{mA} \mathrm{h} \mathrm{g}{ }^{-1}$. They show almost a stable cycling performance until $50^{\text {th }}$ cycle. The reversible charge capacities observed at the end of $50^{\text {th }}$ cycles are 400 and $\left.395 \pm 10\right) \mathrm{mA} \mathrm{h} \mathrm{g}^{-1}$. The SnO.CoOB shows coulombic efficiency of $96-98 \%$ in the range of $5-50^{\text {th }}$ cycle for both the compositions. The calculated specific energy of SnO.CoO-B is $240( \pm 5) \mathrm{W} \mathrm{h} / \mathrm{kg}$, which is lower than SnO-S.

\section{Conclusions}

We prepared $\mathrm{SnO}$ nanoparticles (SnO-S) and $\mathrm{SnO} . \mathrm{CoO}$ nanocomposites (SnO.CoOB) as negative electrode materials for lithium ion batteries (LIBs) by chemical route and high energy ball milling approaches, respectively. The structure and morphology are evaluated by X-ray diffraction (XRD) and transmission electron microscopy (TEM) techniques. The XRD 
shows phase pure formation of $\mathrm{SnO}-\mathrm{S}$, whereas the ball milled nanocomposite consists of $\mathrm{SnO}_{2}$ and Co- metal phases. In both cases, nano-size particles were achieved as confirmed from TEM measurement. The Li- storage performances of SnO-S and SnO.CoO-B are evaluated by galvanostatic cycling and cyclic voltammetry (CV) against Li- metal. Their electrochemical performances are compared to that of commercial micron size $\mathrm{SnO}(\mathrm{SnO}-\mathrm{C})$ and ball milled $\mathrm{SnO}$ ( $\mathrm{SnO}-\mathrm{B})$. The $\mathrm{SnO}-\mathrm{S}$ and $\mathrm{SnO} \cdot \mathrm{CoO}-\mathrm{B}$ showed improved cycling performance due to their finite particle size (i.e. nano-size) and presence of secondary phase (CoO). They showed a high reversible charge capacity of 450 and $400( \pm 10) \mathrm{mA} \mathrm{h} \mathrm{g}^{-1}$, respectively after $50^{\text {th }}$ cycle with capacity fading of 3.7 and $1.2 \mathrm{~mA} \mathrm{~h} \mathrm{~g}^{-1}$ per cycle. These values are still higher than that of SnO-C and SnO-B, which show capacity fading of 21.3 and $7.7 \mathrm{~mA} \mathrm{~h} \mathrm{~g}^{-1}$ per cycle. Also, addition of carbon nanotubes (CNT) to SnO-S further improved the cycling performance of SnO-S. When cycled at $60 \mathrm{~mA} \mathrm{~g}{ }^{-1}$, it showed a high reversible capacity of $500( \pm 10) \mathrm{mA} \mathrm{h} \mathrm{g}^{-1}$ at the end of $50^{\text {th }}$ cycle with capacity fading of 1.8 $\mathrm{mA} \mathrm{h} \mathrm{g}^{-1}$ per cycle. The coulombic efficiency for all the samples is, $96-98 \%$ in the range of 5-50 cycles.

\section{Acknowledgements}

Authors thank to Defense Advanced Research Projects Agency (DARPA), USA (Grant no. R-144-000-226-597). Dr. B.K. Das thanks to NUS for providing NUS fellowship. Authors declare no financial interest. 


\section{References}

[1] A. Kamyshny, S. Magdassi, Conductive Nanomaterials for Printed Electronics, Small 10 (2014) 3515.

[2] G. R. Patzke, F. Krumeich, R. Nesper, Oxidic Nanotubes and Nanorods-Anisotropic Modules for a Future Nanotechnology, Angew. Chem. Int. Ed. 41 (2002) 2446.

[3] J. A. Barreto, W. O`Malley, M. Kubeil, B. Graham, H. Stephan, L. Spiccia, Nanomaterials : applications in cancer imaging and therapy, Adv. Mater. 23 (2011) H18.

[4] J. Gao, B. Xu, Applications of nanomaterials inside cells, Nano Today 4 (2009) 37.

[5] A. S. Arico, P. Bruce, B. Scrosati, J. M. Tarascon, W. van Schalkwijk, Nanostructured materials for advanced energy conversion and storage devices, Nature Mater. 4 (2005) 366.

[6] X. Zhao, B. M. Sanchez, P. J. Dobson, P. S. Grant, The role of nanomaterials in redoxbased supercapacitors for next generation energy storage devices, Nanoscale 3 (2011) 839.

[7] Q. Zhang, E. Uchaker, S. L. Candelaria, G. Cao, Nanomaterials for energy conversion and storage, Chem. Soc. Rev. 42 (2013) 3127.

[8] (a) Y. G. Guo, J. S. Hu, L. J. Wan, Nanostructured Materials for Electrochemical Energy Conversion and Storage Devices, Adv. Mater. 20 (2008) 2878.

(b) Q. Zheng, X. Zhang, Y. Shen, Fabrication of free-standing NiCo2O4 nanoarrays via a facile modified hydrothermal synthesis method and their applications for lithium ion batteries and high-rate alkaline batteries, Mater. Res. Bull. 63 (2015) 211-215.

[9] H. Jiang, J. Ma, C. Li, Mesoporous carbon incorporated metal oxide nanomaterials as supercapacitor electrodes, Adv. Mater. 24 (2012) 4197.

[10] P. G. Bruce, B. Scrosati, J. M. Tarascon, Nanomaterials for rechargeable lithium batteries, Angew. Chem. Int. Ed. 47 (2008) 2930. 
[11] (a) J. Hassoun, F. Bonaccorso, M. Agostini, M. Angelucci, M. G. Betti, R. Cingolani, M. Gemmi, C. Mariani, S. Panero,V. Pellegrini, B. Scrosati, An advanced lithium-ion battery based on a graphene anode and a lithium iron phosphate cathode, Nano Lett. 14 (2014) 4901. (b) X. Liu, D. Chao, Y. Li, J. Zhao, J. Lin, H. J. Fan, Z. X. Shen, A low-cost and one-step synthesis of $\mathrm{N}$-doped monolithic quasi-graphene films with porous carbon frameworks for Li-ion batteries, Nano Energy, 17 (2015) 43-51.

[12] S. Li, Y. Luo, W. Lv, W. Yu, S. Wu, P. Hou, Q. Yang, Q. Meng, C. Liu, H. M. Cheng, Vertically Aligned Carbon Nanotubes Grown on Graphene Paper as Electrodes in LithiumIon Batteries and Dye-Sensitized Solar Cells, Adv. Energ. Mater. 1 (2011) 486.

[13] X. Xia, D. Chao, Y. Zhang, Z. X. Shen, H. J. Fan, Three-Dimensional Graphene and Their Integrated Electrodes, Nano Today 9 (2014) 785-807.

[14] P. Poizot, S. Laruelle, S. Grugeon, L. Dupont, J.-M. Tarascon, Nano-sized transitionmetal oxides as negative-electrode materials for lithium-ion batteries, Nature 407 (2000) 496.

[15] M. V. Reddy, G. V. Subba Rao, B.V.R. Chowdari, Metal Oxides and Oxysalts as Anode Materials for Li Ion Batteries, Chem. Rev. 113 (2013) 5364.

[16] (a) M. Gao, P. Zhou, P. Wang, J. Wang, C. Liang, J. Zhang, Y. Liu, FeO/C anode materials of high capacity and cycle stability for lithium-ion batteries synthesized by carbothermal reduction, J. Alloys Compd. 565 (2013) 97.

(b) F. Cao, G.X. Pan, P.S. Tang, H.F. Chen, NiO nanowall array prepared by a hydrothermal synthesis method and its enhanced electrochemical performance for lithium ion batteries, Mater. Res. Bull. 48 (2013) 1178-1183.

[17] M. Chen, X. Xia, M. Qi, J. Yuan, J. Yin, Q. Chen, Self-supported porous CoO semisphere arrays as binder-free electrodes for high-performance lithium ion batteries, Mater. Res. Bull. 73 (2016) 125-129. 
[18] C. Guan, X.Wang, Q. Zhang, Z. Fan, H. Zhang, H. J. Fan, Highly Stable and Reversible Lithium Storage in $\mathrm{SnO}_{2}$ Nanowires Surface Coated With A Uniform Hollow Shell by Atomic Layer Deposition, Nano Lett. 14 (2014) 4852-4858.

[19] N. Du, H. Zhang, B. Chen, X. Ma, X. Huang, J. Tu, D. Yang, Synthesis of polycrystalline $\mathrm{SnO} 2$ nanotubes on carbon nanotube template for anode material of lithiumion battery, Mater. Res. Bull. 44 (2009) 211-215.

[20] (a) Y. Xu, Q. Liu, Y. Zhu, Y. Liu, A. Langrock, M. R. Zachariah, C. Wang, Uniform nano Sn/C composite anodes for lithium ion batteries, Nano Lett. 13 (2013) 470.

(b) C.-L. Zhu, M.-L. Zhang,Y.-J. Qiao, P. Gao, Y.-J. Chen, High capacity and good cycling stability of multi-walled carbon nanotube/SnO2 core-shell structures as anode materials of lithium-ion batteries, Mater. Res. Bull. 45 (2010) 437-441.

[21] L. Zou, L. Gan, F. Kang, M. Wang, W. Shen, Z. Huang, Sn/C non-woven film prepared by electrospinning as anode materials for lithium ion batteries, J. Power Sources 195 (2010) 1216.

[22] (a) M. V. Reddy, G. V. Subba Rao, B. V. R. Chowdari, Nano-( $\left.\mathrm{V}_{1 / 2} \mathrm{Sb}_{1 / 2} \mathrm{Sn}\right) \mathrm{O}_{4}$ : a high capacity, high rate anode material for Li-ion batteries, J. Mater. Chem. 21 (2011) 10003.

(b) W. W. Zhou, C. W. Cheng, J. P. Liu, Y.Y. Tay, J. Jiang, X.T. Jia, J. X. Zhang, H. Gong, H. H. Hng, T. Yu, H. J. Fan, Epitaxial Growth of Branched $a-\mathrm{Fe}_{2} \mathrm{O}_{3} / \mathrm{SnO}_{2}$ Nanoheterostructure with Improved Lithium-Ion Battery Performance, Adv. Funct. Mater. 21 (2011) 2439-2445.

[23] M. V. Reddy, G. V. Subba Rao, B. V. R. Chowdari, Li-storage and cycling properties of Sn-Sb-mixed oxides, $\left(\mathrm{M}_{1 / 2} \mathrm{Sb}_{1 / 2} \mathrm{Sn}\right) \mathrm{O}_{4}, \mathrm{M}=\mathrm{In}, \mathrm{Fe}, \mathrm{J}$. Solid State Electrochem. 17 (2013) 1765. 
[24] M. V. Reddy, V. H. Khai, B. V. R.Chowdari, Electrochemical properties of reheated molten salt synthesized $\left(\mathrm{M}_{1 / 2} \mathrm{Sb}_{1 / 2} \mathrm{Sn}\right) \mathrm{O}_{4}(\mathrm{M}=\mathrm{V}, \mathrm{Fe}, \mathrm{In})$ cycled in the voltage range of 0.005-1.0 and 0.005-3.0 V, Solid State Ionics 268 (2014) 277.

[25] M. V. Reddy, V. H. Khai, B. V. R.Chowdari, Facile one pot molten salt synthesis of nano $\left(\mathrm{M}_{/ 2} \mathrm{Sb}_{1 / 2} \mathrm{Sn}\right) \mathrm{O}_{4}(\mathrm{M}=\mathrm{V}, \mathrm{Fe}, \mathrm{In})$, Mater. Lett. 140 (2015) 115.

[26] B. Das, M. V. Reddy, G. V. Subba Rao, B. V. R. Chowdari, Nano-composites $\mathrm{SnO}\left(\mathrm{VO}_{\mathrm{x}}\right)$ as anodes for lithium ion batteries, J. Solid State Electrochem. 15 (2011) 259.

[27] Q. Tian, Y. Tian, Z. Zhang, L. Yang, S. Hirano, Facile synthesis of ultrasmall tin oxide nanoparticles embedded in carbon as high-performance anode for lithium-ion batteries, J. Power Sources 269 (2014) 479.

[28] Y. Hu, K. Xu, L. Kong, H. Jiang, L. Zhang, C. Li, Flame synthesis of single crystalline SnO nanoplatelets for lithium-ion batteries, J. Chem. Eng. 242 (2014) 220.

[29] H. Zhang, Q. He, F. Wei, Y. Tan, Y. Jiang, G. Zheng, G. Ding, Z. Jiao, Ultrathin SnO nanosheets as anode materials for rechargeable lithium-ion batteries, Mater. Lett. 120 (2014) 200.

[30] Q. Tian, Z. Zhang, L. Yang, S. Hirano, Fabrication of mesoporous titanium dioxide/tin dioxide/carbon hollow microspheres as high performance anode for lithium-ion batteries, J. Power Sources 279 (2015) 528.

[31] X. Liu, J. Zhang, W. Si, L. Xi, S. Oswald, C. Yan, O. G. Schmidt, High-rate amorphous $\mathrm{SnO}_{2}$ nanomembrane anodes for Li-ion batteries with a long cycling life, Nanoscale 7 (2015) 282.

[32] B. Das, M. V. Reddy, G. V. Subba Rao, B. V. R. Chowdari, Nano-phase tin hollandites, $\mathrm{K}_{2}\left(\mathrm{M}_{2} \mathrm{Sn}_{6}\right) \mathrm{O}_{16}(\mathrm{M}=\mathrm{Co}, \mathrm{In})$ as anodes for Li-ion batteries, J. Mater. Chem. 21 (2011) 1780. 
[33] E. T. H. Tan, G. W. Ho, A. S. W. Wong, S. Kawi, A. T. S. Wee, Gas sensing properties of tin oxide nanostructures synthesized via a solid-state reaction method, Nanotechnology 19 (2008) 255706.

[34] T. Ramireddy, M. M. Rahman, T. Xing, Y. Chen, A. M. Glushenkov, Stable anode performance of an $\mathrm{Sb}$-carbon nanocomposite in lithium-ion batteries and the effect of ball milling mode in the course of its preparation, J. Mater. Chem. A 2 (2014) 4282.

[35] T. Tao, M. M. Rahman, T. Ramireddy, J. Sunarso, Y. Chen, A. M.Glushenkov, Preparation of composite electrodes with carbon nanotubes for lithium-ion batteries by lowenergy ball milling, RSC Advances 4 (2014) 36649.

[36] T. Ramireddy, T. Xing, M. M. Rahman, Y. Chen, Q. Dutercq, D. Gunzelmann, A. M. Glushenkov, Phosphorus-carbon nanocomposite anodes for lithium-ion and sodium-ion batteries, J. Mater. Chem. A 3 (2015) 5572.

[37] B. Das, M. V. Reddy, G. V. Subba Rao, B. V. R. Chowdari, Synthesis of porous-CoN nanoparticles and their application as a high capacity anode for lithium-ion batteries, J. Mater. Chem. 22 (2012) 17505.

[38] B. Das, M. V. Reddy, B. V. R. Chowdari, X-ray absorption spectroscopy and energy storage of $\mathrm{Ni}$-doped cobalt nitride, $\left(\mathrm{Ni}_{0.33} \mathrm{Co}_{0.67}\right) \mathrm{N}$, prepared by a simple synthesis route, Nanoscale 5 (2013) 1961.

[39] B. Das, M. V. Reddy, B. V. R. Chowdari, Li-storage of $\mathrm{Fe}_{3} \mathrm{O}_{4} / \mathrm{C}$ composite prepared by one-step carbothermal reduction method, J. Alloys Compd. 565 (2013) 90.

[40] B. Das, M. V. Reddy, G. V. Subba Rao, B. V. R. Chowdari, Nanoflake CoN as a high capacity anode for Li-ion batteries, Solid State Ionics 180 (2009) 1061.

[41] D. Aurbach, A. Nimberger, B. Markovsky, E. Levi, E. Sominski, A. Gedanken, Nanoparticles of SnO Produced by Sonochemistry as Anode Materials for Rechargeable Lithium Batteries, Chem. Mater. 14 (2002) 4155. 
[42] H. X. Zhang, C. Feng, Y. C. Zhai, K. L. Jiang, Q. Q. Li, S. S. Fan, Cross-Stacked Carbon Nanotube Sheets Uniformly Loaded with $\mathrm{SnO}_{2}$ Nanoparticles: A Novel Binder-Free and High-Capacity Anode Material for Lithium-Ion Batteries, Adv. Mater. 21 (2009) 2299.

[43] Z. Wen, Q. Wang, Q. Zhang, J. Li, In Situ Growth of Mesoporous $\mathrm{SnO}_{2}$ on Multiwalled Carbon Nanotubes: A Novel Composite with Porous-Tube Structure as Anode for Lithium Batteries, Adv. Funct. Mater. 17 (2007) 2772.

[44] X. Wang, X. Cao, L. Bourgeois, H. Guan, S. Chen, Y. Zhong, D.-M. Tang, H. Li, T. Zhai, L. Li, Y. Bando, D. Golberg, N-Doped Graphene-SnO 2 Sandwich Paper for HighPerformance Lithium-Ion Batteries, Adv. Funct. Mater. 22 (2012) 2682. 
Table.1. Capacity, coulombic efficiency and capacity fading at different cycle numbers for SnO-C, SnO-B, SnO-S, SnO@CNT and SnO.CoO-B are given.

\begin{tabular}{|c|c|c|c|c|c|c|}
\hline & $\begin{array}{l}\text { SnO-C } \\
\left(\mathrm{mA} \mathrm{h} \mathrm{g}^{-1}\right)\end{array}$ & $\begin{array}{l}\text { SnO-B } \\
\left(m A g^{-1}\right)\end{array}$ & $\begin{array}{l}\text { SnO-S } \\
\left(\mathrm{mA} \mathrm{h} \mathrm{g}^{-1}\right)\end{array}$ & $\begin{array}{l}\text { SnO@CNT } \\
\left(\mathrm{mAh} \mathrm{g}^{-1}\right)\end{array}$ & $\begin{array}{l}\text { 2/3SnO.1/3CoO-B } \\
\left(\mathrm{mA} \mathrm{h} \mathrm{g}^{-1}\right)\end{array}$ & $\begin{array}{l}\text { 3/4SnO. } 1 / 4 \mathrm{CoO}- \\
\mathrm{B}\left(\mathrm{mA} \mathrm{h} \mathrm{g}^{-1}\right)\end{array}$ \\
\hline $1^{\text {st }}$ disch. & 1500 & 1510 & 1725 & 1810 & 1365 & 1395 \\
\hline $1^{\text {st }}$ charge & 660 & 575 & 635 & 590 & 445 & 460 \\
\hline $2^{\text {nd }}$ disch. & 675 & 600 & 665 & 640 & 460 & 490 \\
\hline $2^{\text {nd }}$ charge & 590 & 565 & 630 & 590 & 445 & 465 \\
\hline $50^{\text {th }}$ disch. & $\begin{array}{l}190 \\
(22 \text { cyc. })\end{array}$ & 195 & 460 & 515 & 400 & 410 \\
\hline $50^{\text {th }}$ charge & $\begin{array}{l}190 \\
(22 \text { cyc. })\end{array}$ & 190 & 450 & 500 & 395 & 400 \\
\hline $\begin{array}{l}\text { Capacity } \\
\text { fading/ } \\
\text { Cycle } \\
\left.(\mathrm{mA} \mathrm{h} \mathrm{g})^{-1}\right)\end{array}$ & 21.3 & 7.7 & 3.7 & 1.8 & 1.0 & 1.2 \\
\hline $\begin{array}{l}\text { Coulombic } \\
\text { efficiency; } \\
\%\end{array}$ & $\begin{array}{l}44 \\
\left(1^{\text {st }} \text { cyc. }\right) \\
96-98(5-50 \\
\text { cyc. })\end{array}$ & $\begin{array}{l}38 \\
\left(1^{\text {st }} \text { cyc. }\right) \\
96-98(5- \\
50 \text { cyc. })\end{array}$ & $\begin{array}{l}37 \\
\left(1^{\text {st }} \text { cyc. }\right) \\
96-98(5- \\
50 \text { cyc. })\end{array}$ & $\begin{array}{l}33 \\
\left(1^{\text {st }} \text { cyc. }\right) \\
96-98 \\
(5-50 \text { cyc. })\end{array}$ & $\begin{array}{l}33\left(1^{\text {st }} \text { cyc. }\right) \\
96-98 \\
(5-50 \text { cyc. })\end{array}$ & $\begin{array}{l}33\left(1^{\text {st }} \text { cyc. }\right) \\
96-98 \\
(5-50 \text { сус. })\end{array}$ \\
\hline
\end{tabular}




\section{Figure captions}

Fig.1. Powder XRD diffraction patterns: (a) SnO-S nanoparticles prepared at $200{ }^{\circ} \mathrm{C}, 3 \mathrm{~h}, \mathrm{Ar}$; (b) SnO-B (i) and SnO.CoO-B (ii) prepared by high energy ball milling for $18 \mathrm{~h}$ in Ar. ( $h k$ l) values are given.

Fig.2. TEM (a) and HR-TEM (b-d) images of SnO-S. Inset is the SAED pattern of SnO-S. TEM (e) and HR-TEM (f) images of SnO.CoO-B nanocomposite. Scale bars are shown.

Fig.3. Cyclic voltammograms of (a) SnO-S in the voltage window of $0.005-1.0 \mathrm{~V}$ and (b) SnO.CoO-B in the voltage window of $0.005-0.8 \mathrm{~V}$ at scan rate of $58 \mathrm{~V} \mathrm{~s}^{-1}$.

Fig.4. Galvanostatic cycling of SnO-S: (a) $1^{\text {st }}$ cycle and (b) 2-50 cycles. SnO@CNT: (c) $1^{\text {st }}$ cycle and (d) 2-50 cycles. Voltage window: 0.005-0.8 V. Current density: $60 \mathrm{~mA} \mathrm{~g}^{-1}$.

Fig.5. Galvanostatic cycling of SnO.CoO-B: (a) $1^{\text {st }}$ cycle and (b) 2-50 cycles. Differential capacity vs. voltage plots of SnO.CoO-B: (c) $1^{\text {st }}$ cycle and (d) $2^{\text {nd }}$ and $50^{\text {th }}$ cycle. Voltage window: 0.005-0.8 V. Current density: $60 \mathrm{~mA} \mathrm{~g}^{-1}$.

Fig.6. Capacity vs. cycle number plots : (a) SnO-C, SnO-B, SnO-S and SnO@CNT. (b) $2 / 3 \mathrm{SnO} .1 / 3 \mathrm{CoO}-\mathrm{B}$ and $3 / 4 \mathrm{SnO} \cdot 1 / 4 \mathrm{CoO}-\mathrm{B}$ nanocomposites. Coulombic efficiency vs. cycle number plots for (c) SnO-S, SnO-B and SnO@CNT. (d) 2/3SnO.1/3CoO-B and 3/4SnO. $1 / 4 \mathrm{CoO}-\mathrm{B}$ nanocomposites. 


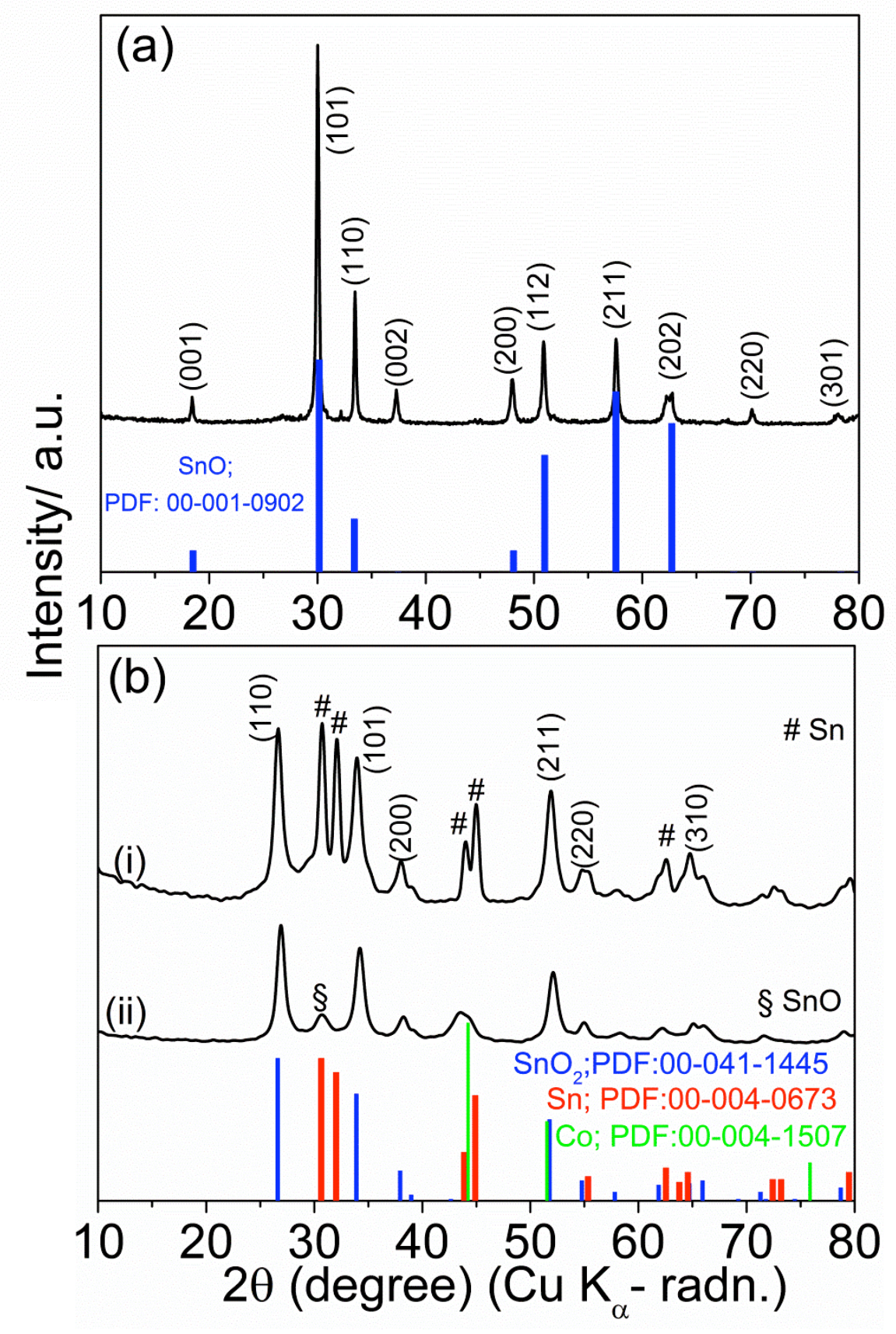

Fig. 1

Das et al. 


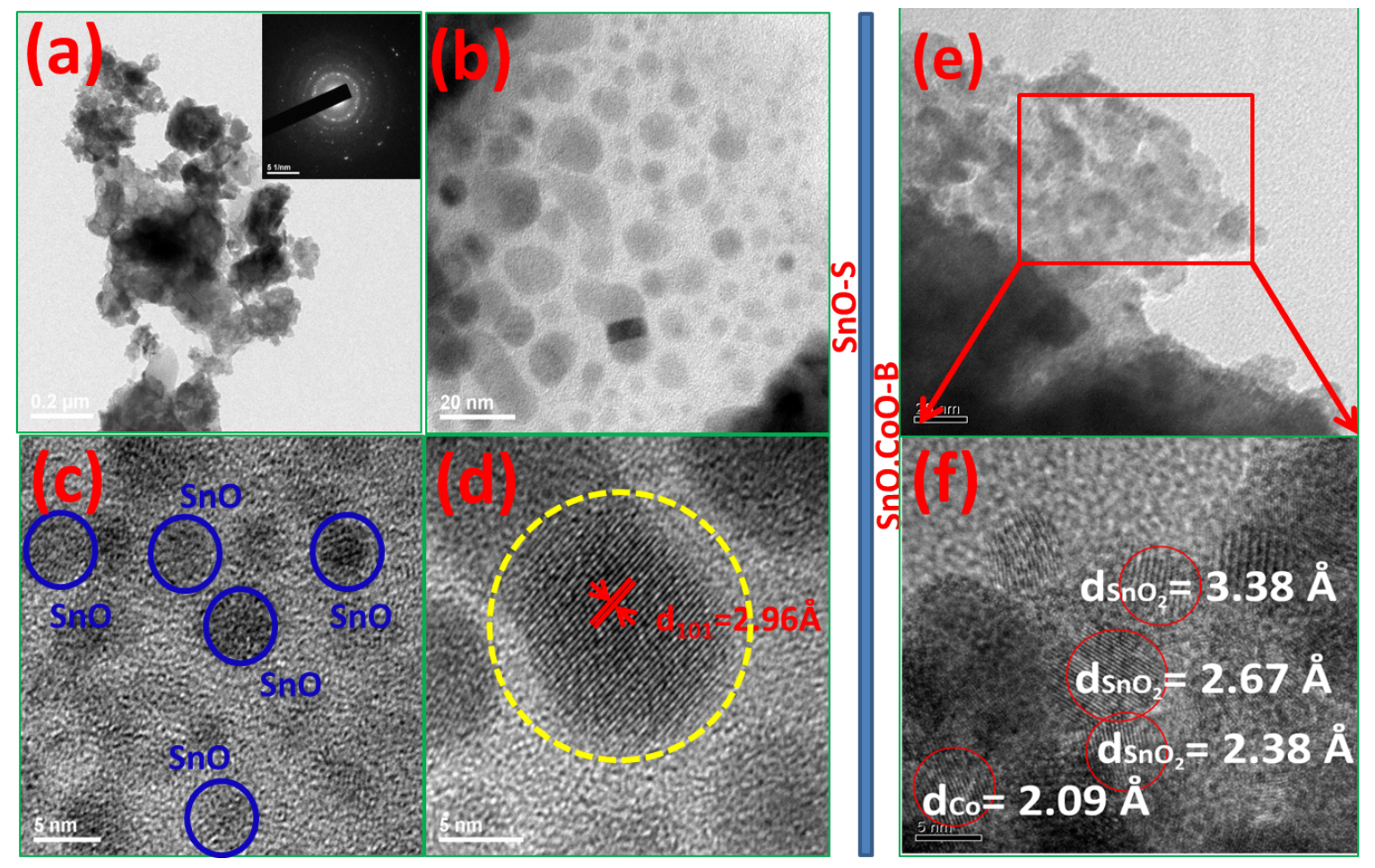

Fig. 2

Das et al. 


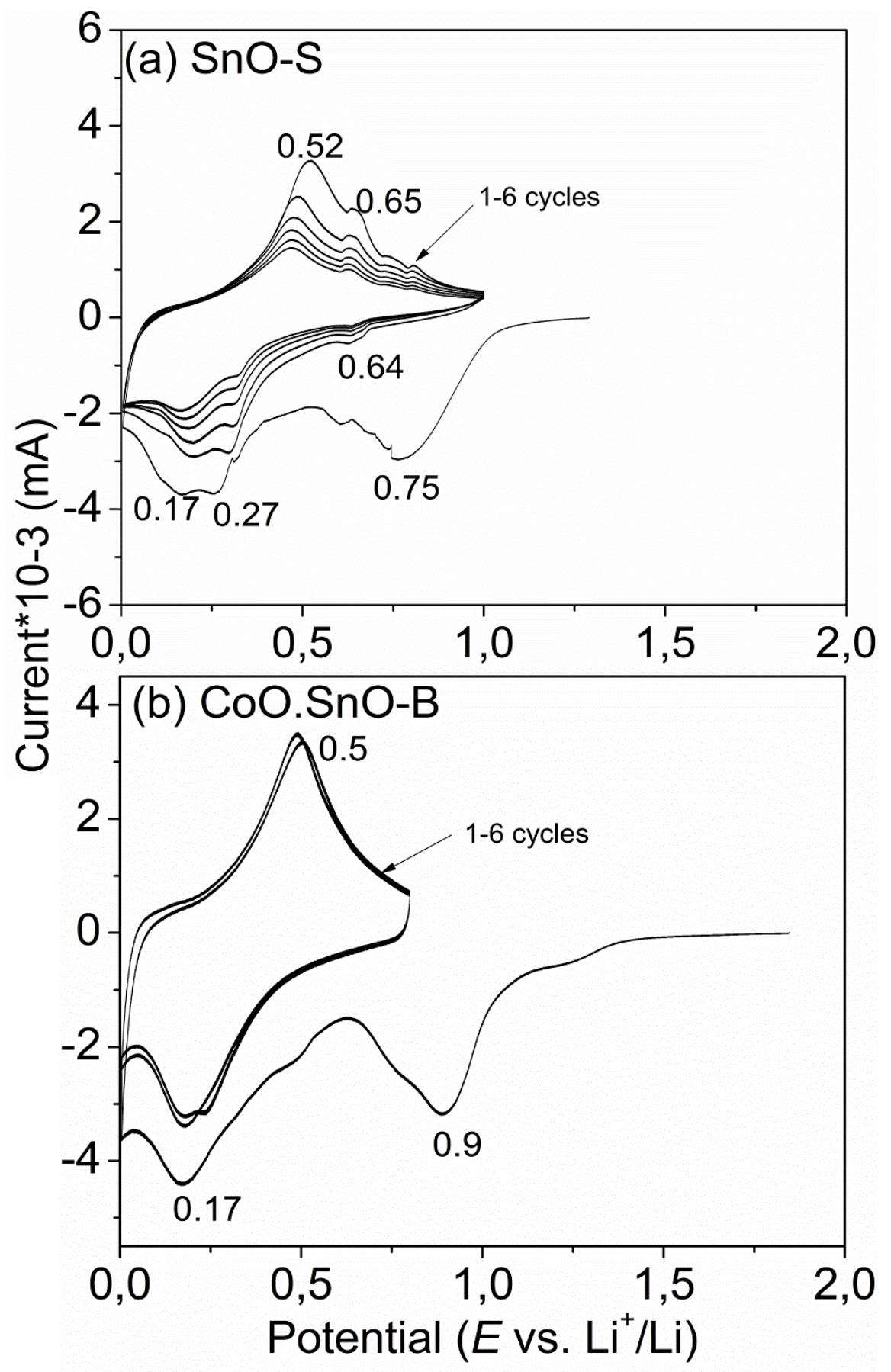

Fig. 3

Das et al. 


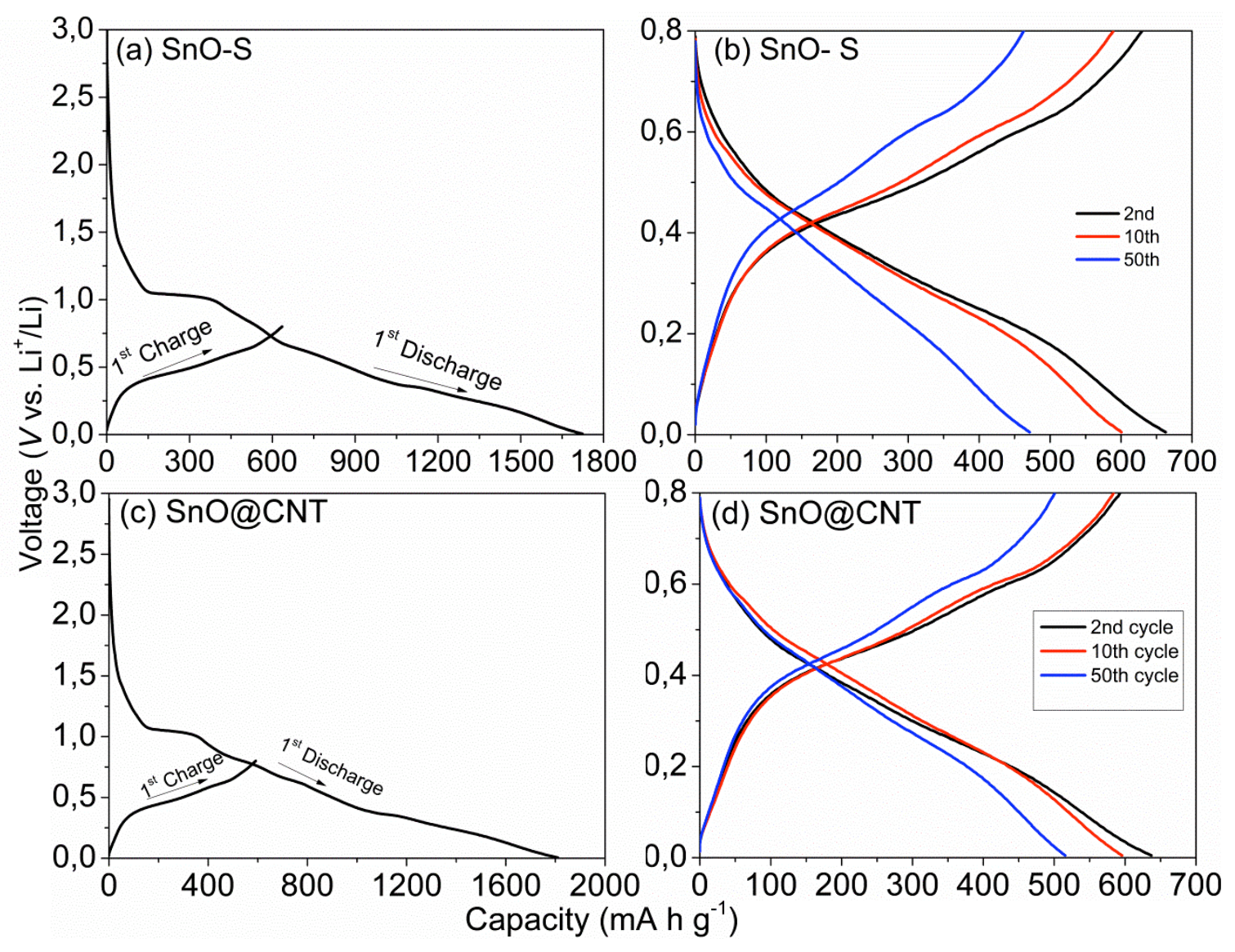

Fig. 4

Das et al. 

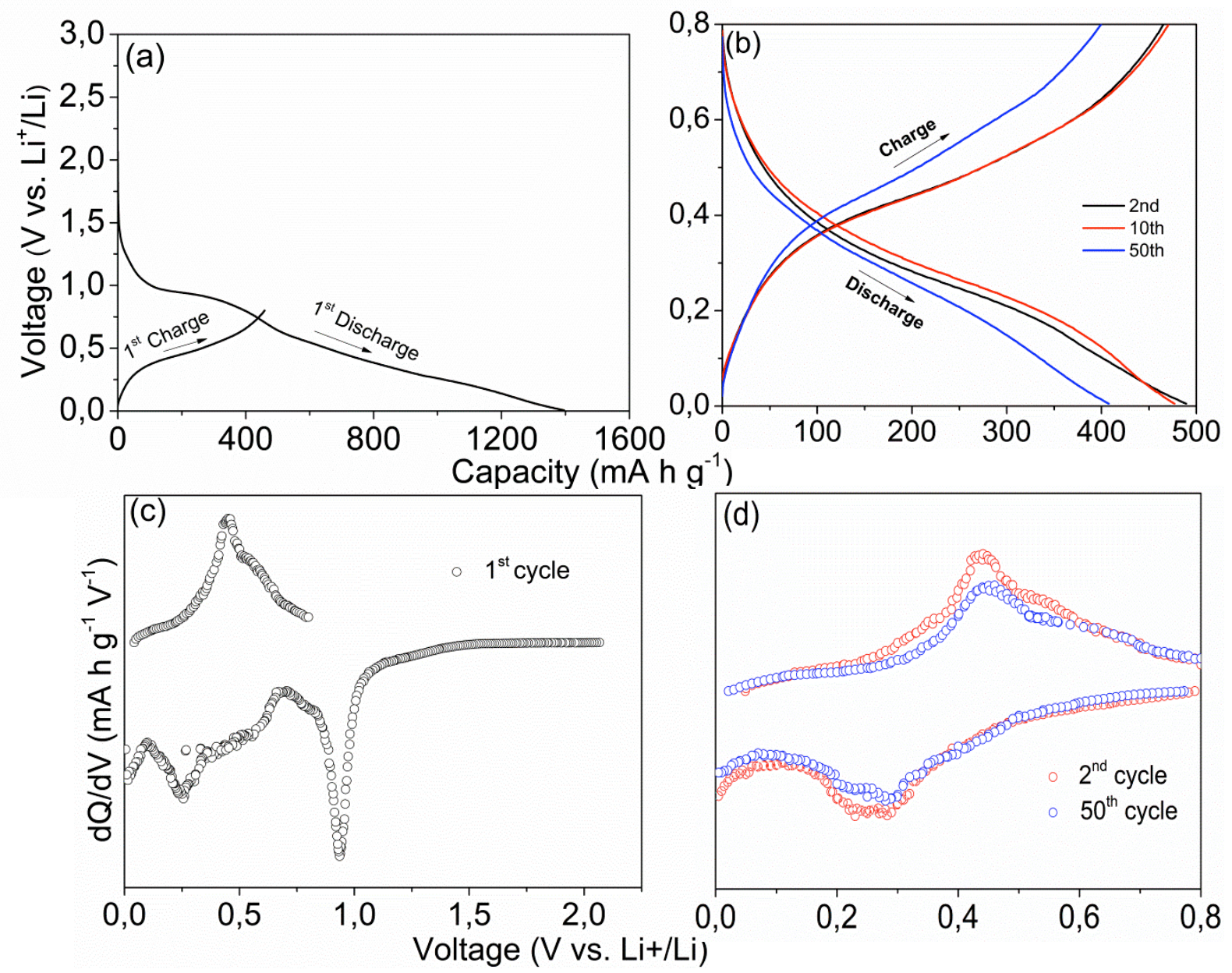

Fig. 5

Das et al. 

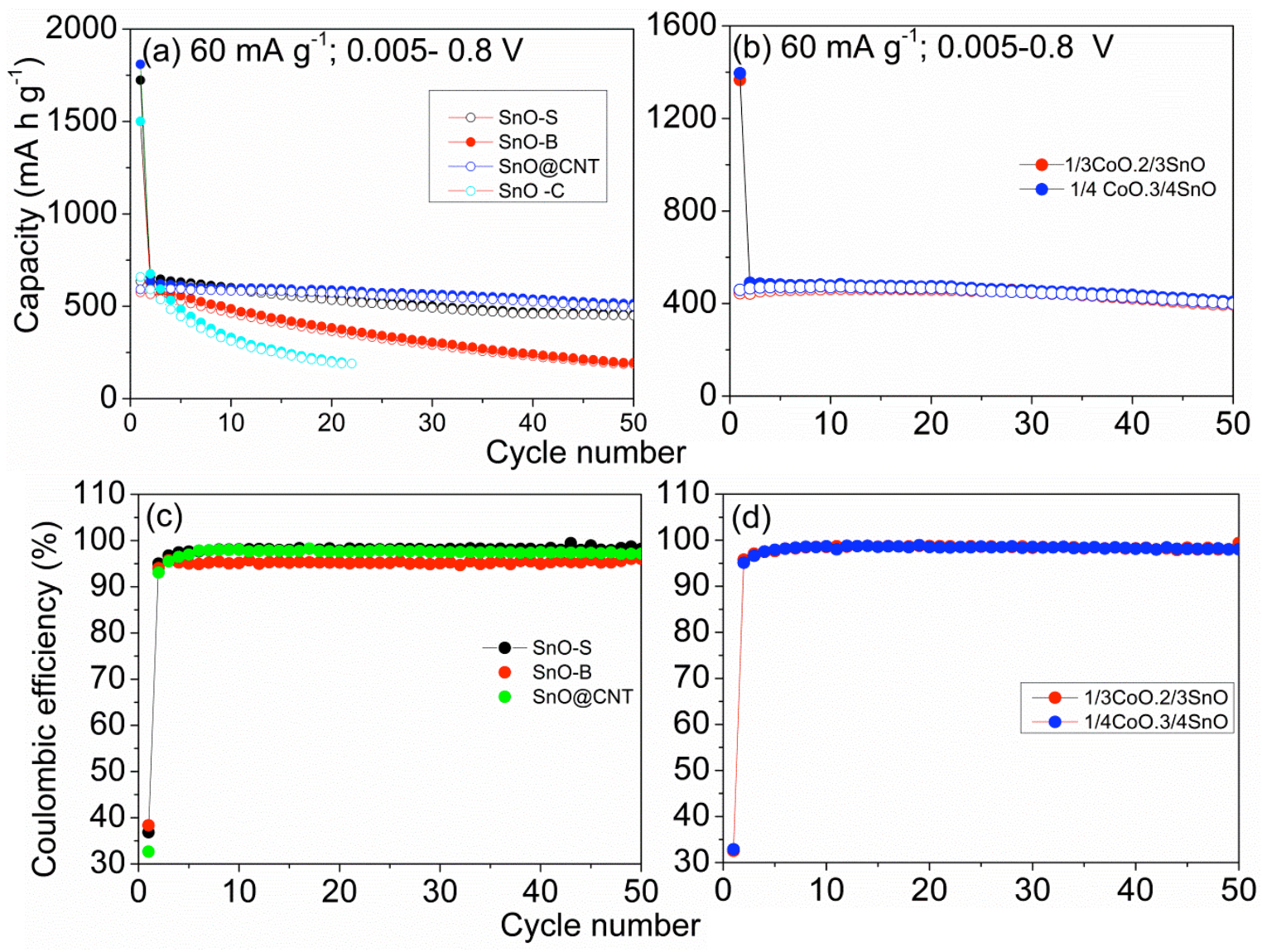

Fig. 6

Das et al. 